\title{
Development of fixed-time artificial insemination protocols for locally adapted Curraleiro Pé-Duro cows
}

\author{
[Desenvolvimento de protocolos de inseminação artificial em tempo fixo em vacas da raça localmente \\ adaptada Curraleiro Pé-Duro] \\ R.D. Tortorella ${ }^{1}$, M.R. Modesto ${ }^{2}$, J.P. Neves ${ }^{1}$, A.F. Ramos ${ }^{3,1^{*}}$ \\ ${ }^{1}$ Universidade de Brasília - UnB - Brasília, DF \\ ${ }^{2}$ Faculdades Integradas da União Educacional do Planalto Central - FACIPLAC - Gama, DF \\ ${ }^{3}$ Embrapa Recursos Genéticos e Biotecnologia - CENARGEN - Brasília, DF
}

\begin{abstract}
Two experiments were conducted aiming to evaluate the effects of two ovulatory inducers (Exp.1) and equine chorionic gonadotropin (eCG; Exp.2) on follicular and luteal dynamics in a fixed-time AI (FTAI) protocol in locally adapted Curraleiro Pé-Duro cows. In Exp. 1 multiparous cows $(\mathrm{n}=12)$ received an intravaginal device containing $1 \mathrm{~g}$ of progesterone (P4) for 8 days and $2 \mathrm{mg}$ of estradiol benzoate (EB) intramuscularly (IM) at device insertion (Day 0). At device removal (Day 8) $0.150 \mathrm{mg}$ of Sodium DCloprostenol was administered IM and the cows were randomly assigned to receive $1 \mathrm{mg}$ of EB (EB8) or $1 \mathrm{mg}$ of estradiol cypionate (EC8) IM, or to not receive any ovulatory inducer (Control). All the animals participated in all treatments (crossover). The interval from $\mathrm{P} 4$ removal to ovulation was shorter and less variable in the EB8 treatment group ( $\mathrm{P} \leq 0.05)$. In Exp. 2 (crossover), multiparous cows $(\mathrm{n}=12)$ received the same hormonal treatment as the EB8 group in Exp.1. At device removal (Day 8) cows were randomly assigned to receive 300UI of eCG IM or to not receive eCG (Control). No difference was ascertained on follicular and luteal parameters in Exp. 2 ( $\mathrm{P}>0.05)$. We concluded that EB can be used as the ovulatory inducer (Exp. 1) in a FTAI protocol in Curraleiro Pé-Duro cows. However, eCG (Exp. 2) was not able to stimulate follicular and luteal development. This result is probably due to the adaptive capacity of Curraleiro Pé-Duro cows that maintained a satisfactory body condition score even in dry and hot environments.
\end{abstract}

Keywords: conservation, estradiol benzoate, estradiol cypionate, equine chorionic gonadotropin, follicular dynamics

\section{RESUMO}

Foram realizados dois experimentos com o objetivo de avaliar o efeito de dois indutores da ovulação $e$ da gonadotrofina coriônica equina (eCG) na dinâmica folicular e luteal, em um protocolo de inseminação artificial em tempo fixo (IATF) em vacas localmente adaptadas da raça Curraleiro PéDuro. No experimento 1 , vacas pluriparas receberam um dispositivo intravaginal contendo $1 \mathrm{~g}$ de progesterona (P4) durante oito dias e $2 \mathrm{mg}$ de benzoato de estradiol (BE) intramuscular (IM) no momento da inserção do dispositivo (dia zero). Na retirada do dispositivo (dia oito), as vacas receberam 0,150mg de D-cloprostenol sódico IM e foram separadas aleatoriamente para receber $1 \mathrm{mg}$ de BE IM (BE8) ou Img de cipionato de estradiol IM (CE8), ou nenhum indutor da ovulação (controle). Todos os animais participaram de todos os tratamentos (crossover). O intervalo entre a retirada da P4 e a ovulação foi menor e menos variável no tratamento $B E 8(P \leq 0,05)$. O momento da ovulação foi mais precoce e mais concentrado nos animais do grupo BE 8. No experimento 2 (crossover), vacas pluríparas receberam o mesmo tratamento hormonal do grupo BE8 do experimento1. Na retirada do dispositivo (dia 8), as vacas foram separadas aleatoriamente para receberem $300 U I$ de eCG IM, enquanto o controle não. Não houve

Recebido em 29 de junho de 2015

Aceito em 29 de março de 2016

*Autor para correspondência (corresponding author)

E-mail: alexandre.floriani@embrapa.br 
diferença nos parâmetros foliculares e luteais avaliados no experimento $2(P>0,05)$. Em conclusão, o BE pode ser utilizado como indutor da ovulação (experimento 1) em protocolos de IATF em vacas Curraleiras Pé-Duro. Entretanto, o eCG (experimento 2) não foi capaz de estimular o desenvolvimento folicular e luteal. Esse resultado é devido provavelmente à capacidade adaptativa das vacas Curraleiras Pé-Duro em manter uma condição corporal satisfatória mesmo em condições de clima seco e quente.

Palavras-chave: conservação, benzoato de estradiol, cipionato de estradiol, gonadotrofina coriônica equina, dinâmica folicular

\section{INTRODUCTION}

The global growth of the human population has led to an increased demand for animal protein. Meanwhile, crop production has taken over the land previously used for raising livestock (Anual..., 2013). Thus, it becomes essential to increase livestock productivity by raising more animals, on smaller areas of land, at lower costs and with higher efficiency. Moreover, the prospect of global climate change raising temperatures and changing the distribution of rainfall over the years (Marengo, 2008) increases the need to use genotypes that are more adaptive to harsh environments (Mariante et al., 2008).

Raised extensively with little or no attention paid to nutritional, health, or reproductive management, locally adapted breeds, such as the Curraleiro Pé-Duro, became extremely hardy and resistant to diseases and parasites, as well as dry and hot climates (Egito et al., 2002; Bianchini et al., 2006). Despite these desirable characteristics, locally adapted breeds began to decrease in numbers due to cross-breeding with exotic Bos taurus and Bos indicus breeds (Fioravanti et al., 2011).

Fixed-time artificial insemination (FTAI) could be useful in the conservation and rapid multiplication of Curraleiro Pé-Duro cattle, allowing better use of underutilized areas for raising livestock in dry tropical climates. FTAI has a significant positive impact on reproductive efficiency by inducing cyclicity in postpartum cows and allowing artificial insemination (AI) without estrus detection with pregnancy rates of around $50 \%$ early in the breeding season (Sá Filho et al., 2013). FTAI hormonal protocols, used commercially for Bos taurus and Bos indicus breeds, have not yet been tested in locally adapted breeds such as the Curraleiro PéDuro. Therefore, these experiments sought to develop a FTAI protocol for Curraleiro Pé-Duro cows through analysis of ovarian responses influenced by (1) a standard hormonal protocol using progesterone (P4) and estradiol benzoate (EB); (2) 2 ovulatory inducers; and (3) eCG.

\section{MATERIALS AND METHODS}

All procedures described herein were approved by the Animal Health and Welfare Committee at the Embrapa Genetic Resources and Biotechnology Center (protocol number 02/2013).

The experiments were conducted in the Sucupira Experimental Station, which is a part of the Embrapa Genetic Resources and Biotechnology Research Center, located in the South-western region of Brasília - Federal District, Brazil $\left(15^{\circ} 52^{\prime}-15^{\circ} 56^{\prime} \mathrm{S}\right.$ e $\left.48^{\circ} 00^{\prime}-48^{\circ} 02^{\prime} \mathrm{O}\right)$, with altitudes ranging from 1050 to $1250 \mathrm{~m}$. The climate is the Koppen Aw, indicating dry winters (relative humidity can be as low as $10 \%$ ) and rainy summers. Prior to the beginning of the experiments, all of the cows were submitted to a gynecological examination using rectal palpation, ultrasonography (Mindray 2200 Vet, Shenzhen, China, equipped with a $7.5 \mathrm{MHz}$ transrectal transducer) and vaginoscopy, in order to ascertain the absence of diseases or abnormalities in their reproductive tract. For the duration of the experiments (rainy - Experiment 1 or dry season - Experiment 2), all cows were kept in pasture (Brachiaria decumbens), supplemented with mineral salt and ad libitum access to water.

In Experiment 1 (Exp. 1), the aim was to evaluate the effects of three different protocols using $\mathrm{EC}, \mathrm{EB}$ or no ovulatory inducer on follicular and luteal development. Cyclic, nonlactating (last calving occurred 6 months before), multiparous Curraleiro Pé-Duro cows $(\mathrm{n}=12)$ ranging from 3 to 8 years old, with a mean body condition score (BCS) of 3 ranging from 2.75 to 3.25 on a scale from 1 to 5 where $1=$ emaciated and $5=$ obese (Wildman et al., 1982) were used 
in this study. For the duration of the experiment (rainy season), all cows were kept in pasture (Brachiaria decumbens), supplemented with mineral salt and ad libitum access to water.

The animals $(n=12)$ were divided into 3 treatment groups: EB8, EC8 and Control, and the experiment was designed to allow all animals to participate in all treatments (crossover with three replicates; e.g., 12 cows per treatment group). The interval between replicates was 15 days to allow the beginning of a new follicular wave. All animals received an intravaginal device during 8 days containing $1 \mathrm{~g}$ of P4 (Sincrogest; Ouro Fino,
Cravinhos, São Paulo, Brazil) and 2mg of EB intramuscularly (IM; Gonadiol; Intervet Schering, Cotia, São Paulo, Brazil) upon insertion of the device (Day 0). Upon removal of the device (Day 8) one dose of $0.150 \mathrm{mg}$ of Sodium D-Cloprostenol $\left(\mathrm{PGF}_{2 \alpha} ; \quad\right.$ Prolise; Tecnopec LTDA, São Paulo, Brazil) was administered IM and the animals were randomly assigned to receive $1 \mathrm{mg}$ of $\mathrm{EB}(\mathrm{EB} 8, \mathrm{n}=12)$ or $1 \mathrm{mg}$ of estradiol cypionate (EC8, n=12; E.C.P.; Pfizer Animal Health, São Paulo, São Paulo, Brazil) IM, or to not receive any ovulatory inducer (Control, $\mathrm{n}=12$; Fig.1) at the device removal.

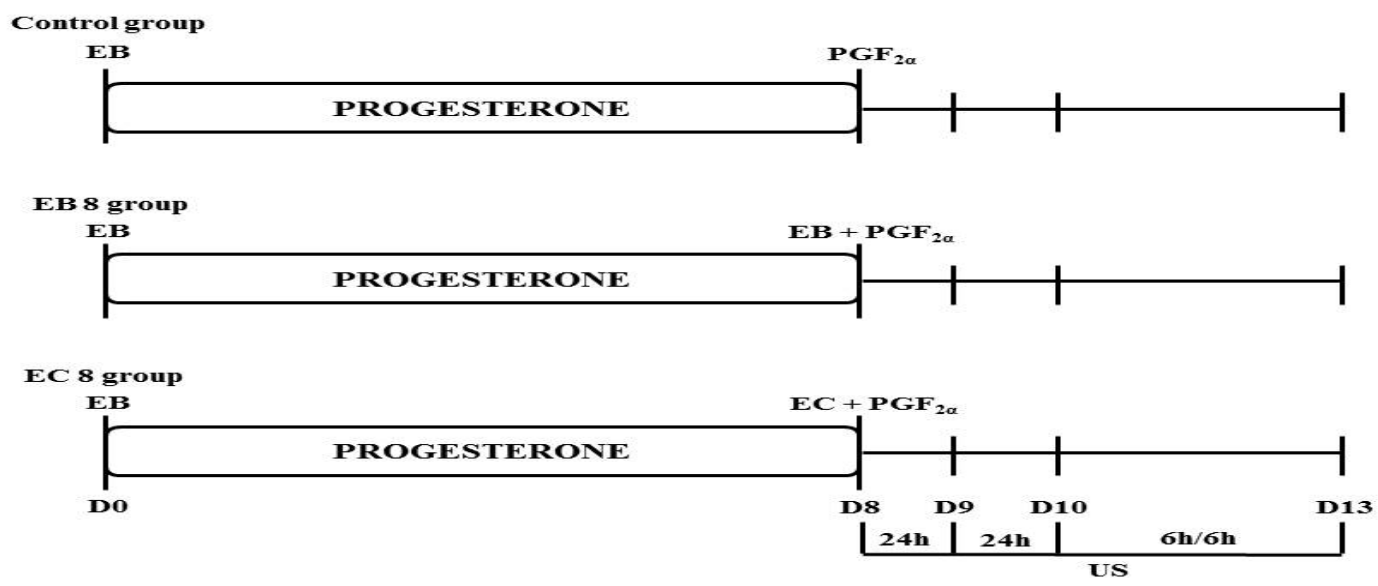

Figure 1. Outline of the experiment. Day 0 (D0): insertion of an intravaginal device containing $1 \mathrm{~g}$ of P4 and administration of $2 \mathrm{mg}$ of EB IM. Day 8 (D8): removal of device and administration of $0.150 \mathrm{mg}$ of Sodium D-Cloprostenol IM (Control group). EB8 group: identical to the Control with the addition of $1 \mathrm{mg}$ of EB IM administered on D8. EC8 group: identical to the Control with the addition of 1mg of EC IM administered on D8. Cows were subjected to an ovarian ultrasound examination every 24 hours from D8 to D10 and subsequently every six hours until ovulation or D13.

Ovarian follicular growth was evaluated every 24 hours from D8 to D10 using a Mindray ultrasound system (Mindray 2200 Vet, Shenzhen, China) equipped with a $7.5 \mathrm{MHz}$ transrectal transducer. During each examination, ovarian maps were drawn to record the diameter and relative position of follicles $\geq 7 \mathrm{~mm}$. The follicular diameter was determined by the average of two measured diameters of each follicle. From D10 to D13 the DF was examined every 6 hours until the identification of the ovulation. Ovulation was defined as the disappearance of a previously identified dominant follicle (DF, $\geq 10 \mathrm{~mm}$ ) from one ultrasound examination to the next, and was confirmed by subsequent detection of a corpus luteum $(\mathrm{CL})$. Interval from $\mathrm{P} 4$ device removal to ovulation (IO) was calculated based on the mean time between the last time the DF was present and the time of disappearance after device removal.

The CL volume was assessed at 5, 10, and 15 days after ovulation using the formula $V=4 / 3 \pi R^{3}$, where $\mathrm{R}=(\mathrm{Da} / 2+\mathrm{Db} / 2) / 2$ and where $\mathrm{Da}$ and $\mathrm{Db}$ were the perpendicular diameters of the CL. If the CL had a cavity, its volume was calculated using the same formula and deleted from the total volume of the CL. Immediately after CL examination, blood samples for the serum P4 analysis were collected via jugular vein using $9 \mathrm{ml}$ tubes (Vacutainer ${ }^{\circledR}$, Beckton \& Dickson, Brasília, Brazil). Immediately after collection, the blood samples were kept at $4^{\circ} \mathrm{C}$ for 10 to 15 
minutes and then centrifuged at $1500 \mathrm{x}$ g for 20 minutes. Subsequently, the serum was removed and stored at $-20^{\circ} \mathrm{C}$ until analyzed. Serum P4 concentrations were determined using a solid phase RIA kit with antibody-coated tubes (Coata-Count DPC, Diagnostic Products Corporation, Los Angeles, CA, USA). The sensitivity of the test was $0.02 \mathrm{ng} / \mathrm{ml}$, and the intra-analysis $\mathrm{CV}$ was $2.8 \%$

In Experiment 2 (Exp. 2), the aim was to evaluate the effects of eCG on follicular and luteal growth. Cyclic, non-lactating, multiparous Curraleiro Pé-Duro cows $(n=12)$ ranging from 3 to 8 years old, with a mean body condition score (BCS) of 3 ranging from 2.75 to 3.25 on a scale from 1 to 5 , where $1=$ emaciated and $5=$ obese (Wildman et al., 1982), were used in this study.

The animals $(\mathrm{n}=12)$ were divided into 2 treatment groups: eCG and Control, and the experiment was designed to allow all animals to participate in all treatments (crossover with two replicates; e.g., 12 cows per treatment group). The interval between replicates was 15 days to allow the beginning of a new follicular wave. All animals received EB8 treatment as in Exp. 1. Upon removal of the device (Day 8) the animals were randomly assigned to receive 300UI of eCG $\left(n=12\right.$; Folligon $^{\circledR}$, Intervet Schering, Cotia, São Paulo, Brazil) IM or to not receive eCG (Control, $\mathrm{n}=12$ ) at the device removal. Follicular and luteal development and concentration of P4 were analyzed as described in Exp. 1.

Follicular diameter data was analyzed using a MIXED model analysis for repeated data (PROC
MIXED; Statistical, 2004) to determine the main effects, group, and day and the interactions thereof. Differences in follicular diameters on a specific day were compared between groups using the estimate statement. CL volume and P4 concentrations were compared using ANOVA and General Linear Models and the different groups were compared multilaterally using LSMEANS. Data distribution was tested for normality with the Shapiro-Wilk test and normalized when necessary. Ovulation rate was analyzed using the nonparametric test used in the PROC CATMOD, and post hoc analyses performed by contrasts of maximum likelihood estimates. An F test on the ratio of variances among groups was used to evaluate the ovulation concentration performing a comparison between the estimated densities of each group based on the Kernel approximation. The statistical analysis was carried out using SAS 9.1 (Statistical, 2004) and significance was considered for $P \leq 0.05$. Data are presented as the mean \pm standard error of the mean (SEM).

\section{RESULTS}

In Exp. 1, the presence of a DF $>8 \mathrm{~mm}$ at $\mathrm{P} 4$ device removal was observed in $83.33 \%(10 / 12)$ of cows in Control, EB8 and EC8 treatment groups $(\mathrm{P}>0.05)$. Cows without evidence of a DF $(>8 \mathrm{~mm})$ at $\mathrm{P} 4$ device removal were removed from the statistical analysis. There was a day effect on dominant follicle (DF) diameter $(\mathrm{P}<0.001)$ but not a group and group-by-day effect. Ovulation ratios were $7 / 10,5 / 10$ and $9 / 10$ for the EB8, EC8 and Control treatment groups (Tab. 1).

Table 1. Effects of estradiol benzoate (EB) and estradiol cypionate (EC) in a fixed-time AI protocol on the diameter of dominant follicle (D8 and D10), ovulatory follicle (OF), interval to ovulation (IO) and ovulation rate $(\mathrm{OR})$

\begin{tabular}{|llllll|}
\hline \multicolumn{7}{l}{ Dominant follicle diameter $(\mathrm{mm})$} & \multicolumn{2}{l|}{} \\
\hline $\begin{array}{l}\text { Treatment } \\
\text { groups }\end{array}$ & $\mathrm{D} 8(\mathrm{n}=0)$ & $\mathrm{D} 10(\mathrm{n}=10)$ & OF $(\mathrm{n})^{1}$ & $\mathrm{IO}^{2}(\mathrm{~h})$ & OR $(\%)$ \\
\hline EB 8 & $10.8 \pm 0.6$ & $12.1 \pm 0.6$ & $12.3 \pm 0.8(7)$ & $57 \pm 44^{\mathrm{b}}$ & $7 / 10(70)$ \\
ECP 8 & $9 \pm 0.6$ & $10.8 \pm 0.8$ & $13.8 \pm 0.8(5)$ & $84 \pm 55^{\mathrm{a}}$ & $5 / 10(50)$ \\
Control & $9.6 \pm 0.6$ & $12.1 \pm 0.7$ & $13.7 \pm 0.6(9)$ & $93 \pm 6^{\mathrm{a}}$ & $9 / 10(90)$ \\
\hline
\end{tabular}

Data are presented as the mean \pm SEM. There was a day effect on dominant follicle diameter $(\mathrm{P}<0.001)$ but not a group effect and group-by-day effect on the other parameters. ${ }^{a, b}$ Within a column, means without a common superscript differ $(\mathrm{P} \leq 0.05)$. ${ }^{1}$ Cows in which ovulation was not detected were excluded from the analysis. ${ }^{2}$ Interval from $\mathrm{P} 4$ device removal to ovulation (IO) was calculated based on the mean time between the last time the DF was present and the time of disappearance after device removal. 
Interval from $\mathrm{P} 4$ device removal to ovulation (IO) was shorter in the EB8 treatment group $(\mathrm{P} \leq 0.05)$ and the synchronization was higher
(Fig. 2). There was no difference $(\mathrm{P}>0.05)$ in the ovulation synchronization and IO between the Control and EC8 treatment groups.

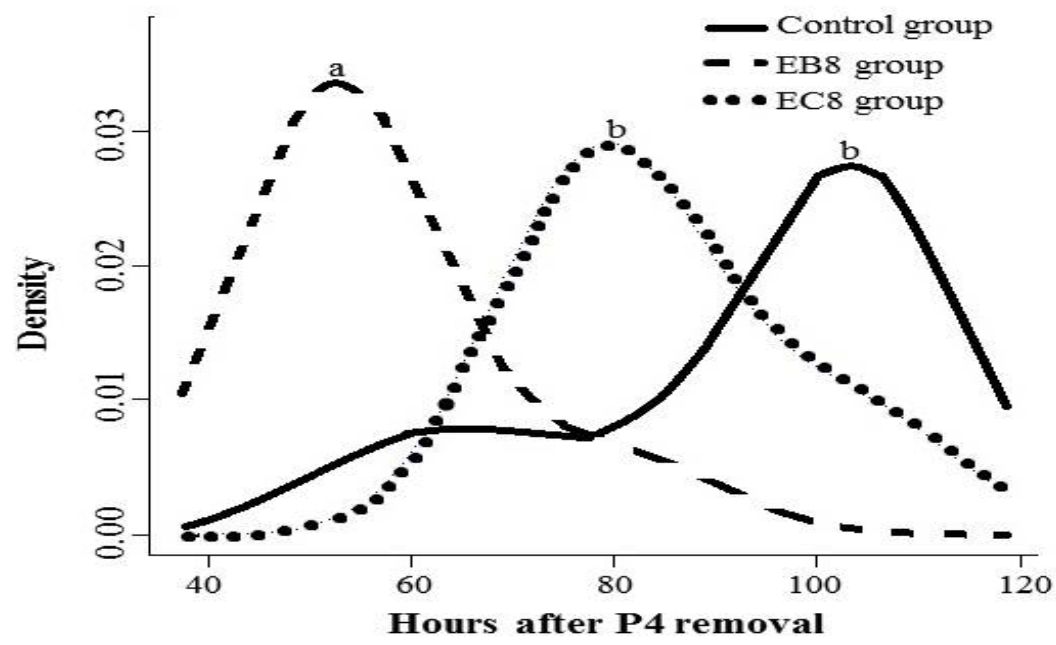

Figure 2. Ovulation distribution after P4 removal (hours) in Curraleiro Pé-Duro cows submitted to FTAI protocols in Control $(n=9)$, EB $8(n=7)$ and EC $8(n=5)$ groups. Different letters indicate a significant difference between groups $(\mathrm{P}<0.05)$.

There was a day effect $(\mathrm{P}<0.001)$ in $\mathrm{CL}$ volume and $\mathrm{P} 4$ concentration but not a group effect as well as an interaction group-by-day effect (data not shown).

In Exp. 2, the presence of a DF $>8 \mathrm{~mm}$ at $\mathrm{P} 4$ device removal was observed in $75 \%$ and $83.33 \%$ of cows in the Control (9/12) and eCG
$(10 / 12)$ treatment groups respectively $(\mathrm{P}>0.05)$. As in Exp. 1 cows without evidence of follicle growth were removed from the analysis. There was a day effect on DF diameter $(\mathrm{P}<0.01)$ but not a group and group-by-day effect. Interval from P4 device removal to ovulation (IO) and OR (Tab. 2) did not differ between treatment groups.

Table 2. Effects of eCG in a fixed-timed AI protocol on the diameter of dominant follicle (D8 and D10), ovulatory follicle (OF), interval to ovulation (IO) and ovulation rate (OR)

\begin{tabular}{llllll}
\hline \multicolumn{7}{l|}{ Dominant Follicle diamenter $(\mathrm{mm})$} \\
$\begin{array}{l}\text { Treatement } \\
\text { groups }\end{array}$ & $\mathrm{D} 8(\mathrm{n})$ & $\mathrm{D} 10(\mathrm{n})$ & $\mathrm{OF}(\mathrm{n})$ & $\mathrm{IO}^{2}(\mathrm{~h})$ & OR $(\%)$ \\
\hline Control & $8.4 \pm 0.4(9)$ & $10.2 \pm 0.5(9)$ & $10.9 \pm 0.4(6)$ & $68 \pm 9$ & $6 / 9(66.67)$ \\
eCG & $8.9 \pm 0.2(10)$ & $10 \pm 0.3(10)$ & $11.4 \pm 0.3(8)$ & $63 \pm 6$ & $8 / 10(80)$ \\
\hline
\end{tabular}

Data are presented as the mean \pm SEM. There was a day effect on DF sizes $(\mathrm{P}<0.001)$ but not a group effect. ${ }^{1}$ Cows without ovulation detected were excluded from the analysis. ${ }^{2}$ Interval from $\mathrm{P} 4$ device removal to ovulation (IO) was calculated based on the mean time between the last time the DF was present and the time of disappearance after device removal.

One cow from the Control group was considered an outlier and was removed from the analysis to avoid overestimated results. In this cow $\mathrm{P} 4$ concentrations were $9.4,18.1$ and $22.5 \mathrm{ng} / \mathrm{ml}$ at 5 ,
10 and 15 days after ovulation. There was a day effect $(\mathrm{P}<0.01)$ in $\mathrm{CL}$ volume and $\mathrm{P} 4$ concentration but not a group effect as well as an interaction group-by-day (Tab. 3). 
Table 3. Corpus luteum (CL) volume $\left(\mathrm{mm}^{3}\right)$ and progesterone (P4) concentration (ng/ml) 5, 10 e 15 days after ovulation in a fixed-timed AI protocol with eCG administered at the time of $\mathrm{P} 4$ device removal

\begin{tabular}{|lllll}
\hline & \multicolumn{4}{l}{ Days after ovulation } \\
\hline Parameters & Treatment groups & 5 & 10 & 15 \\
\hline CL volume $\left(\mathrm{mm}^{3}\right)$ & Control $(\mathrm{n}=5)$ & $2344 \pm 732$ & $4521 \pm 989$ & $2284 \pm 301$ \\
& eCG $(\mathrm{n}=8)$ & $2310 \pm 455$ & $4452 \pm 655$ & $3767 \pm 525$ \\
P4 concentration $(\mathrm{ng} / \mathrm{ml})$ & Control $(\mathrm{n}=6)$ & $3 \pm 0.7$ & $5.2 \pm 1$ & $5.4 \pm 0.6$ \\
& eCG $(\mathrm{n}=8)$ & $4.1 \pm 0.8$ & $8.5 \pm 1.3$ & $8.5 \pm 0.8$ \\
\hline
\end{tabular}

Data are presented as the mean \pm SEM. There was a day $(\mathrm{P}<0.01)$ effect on $\mathrm{P} 4$ concentration and $\mathrm{CL}$ volume, but not a group effect and group-by-day interaction. ${ }^{1}$ An outlier was removed from the analysis.

\section{DISCUSSION}

To our knowledge, this is the first research studying the effects of FTAI on follicular and luteal development in locally adapted Curraleiro Pé-Duro cows. The main findings of this study were that the ovulatory inducer EB allowed better ovulation synchronization, but eCG was not able to improve DF and CL development.

The hormonal protocol was considered effective in beginning a new follicular wave when the DF had a diameter larger than $8 \mathrm{~mm}$ (follicular divergence occurs around $8.5 \mathrm{~mm}$ ) after $\mathrm{P} 4$ intravaginal device removal. Standard hormonal protocol using $\mathrm{EB}, \mathrm{P} 4$, and $\mathrm{PGF}_{2 \alpha}$ was able to synchronize DF growth in around $80 \%$ of cows. Cows in which the hormonal protocol was not effective were excluded from the analysis to avoid underestimated results. Sales et al. (2012) reported that $6.7 \%$ of cows did not exhibit a DF $(>8.5 \mathrm{~mm})$ after $\mathrm{P} 4$ removal.

In Exp. 1, OF diameter did not differ between groups and the diameter reached was $>12 \mathrm{~mm}$ in all groups. Sartori et al. (2001) reported that ovulatory capacity is dependent in part on follicular size, and full ovulatory capacity was obtained when the DF reached $12 \mathrm{~mm}$ in Bos taurus. This may be one of the reasons why OR did not differ either. However, EB8 and EC8 groups OR were very low compared to other studies that achieved an OR of around $80 \%$ (Ayres et al., 2008; Sales et al., 2012). Prolonging the permanence of P4 intravaginal device from 8 to 9 days could improve this ratio, increasing DF diameter (Colazo et al., 2003), and consequently ovulation and pregnancy rates (Perry et al., 2007).

Interval from $\mathrm{P} 4$ device removal to ovulation (IO) was shorter and less variable when EB was used as an ovulatory inducer. Differences in IO between $\mathrm{EB}$ and $\mathrm{EC}$ are due to distinct molecular esterification, weight, and polarity, thereby leading to changes in absorption and metabolism (Vynckier et al., 1990; Souza et al., 2005). These authors also reported that application of EB led to a greater peak concentration of estradiol-17 $\beta$ (E2) and more rapid increase in the concentration of this hormone than EC. Also, E2 concentration took more time to decrease to baseline levels after EC administration, which was expected due to the low solubility in water and consequent longer half-life of EC compared to EB. Sales et al. (2012) found that EB administration led to a greater, more rapid, less variable, and shorter LH peak than EC.

Sales et al. (2012) did not find any of the differences in ovulation synchronization between EB and EC treated Nelore cows which were observed in Curraleiro Pé-Duro cows. However, in the former experiment, EB was administered one day after the removal of the P4 intravaginal device. EB administration upon removal of the P4 intravaginal device was chosen to decrease the handling and stress of the cows, mainly due to Curraleiro Pé-Duro breeders' inexperience with FTAI. Furthermore, Ross et al. (2004) described no difference in Angus cows in OR, $\mathrm{IO}, \mathrm{DF}$ diameter, OF growth rate, $\mathrm{CL}$ area, $\mathrm{P} 4$ concentration and pregnancy rate between administrating $\mathrm{EB}$ at the removal of the $\mathrm{P} 4$ intravaginal device or 24 hours later. Ayres et al. (2008) demonstrated a larger DF and longer IO in Nelore cows treated with EB 24 hours after P4 intravaginal device removal than those treated at the moment of device removal. However, pregnancy rates were similar when FTAI was done 48 hours after P4 intravaginal device removal regardless of the time of EB application (at device removal or 24 hours after). 
There was no difference in IO between the EC and Control treatment groups. This data is in agreement with other research (Souza et al., 2005), in which E2 concentration was similar between the EC and Control group cows. Thus, in the present study, it would not be necessary to administer EC to the Control group since there were no differences in the reproductive parameters including ovulation synchronization.

CL volume and P4 concentration did not differ between groups probably due to the similar OF diameter. Some authors found that $\mathrm{OF}$ diameter affects CL volume and P4 concentration (Vasconcelos et al., 2001; Tortorella et al., 2013).

In Exp. 2, EB was chosen as an ovulatory inducer due to its greater ovulation synchronization compared to EC. Roelofs et al. (2006) showed that the highest pregnancy rates were achieved when AI was done between 12 and 24 hours before ovulation. Thus, an ovulatory inducer that leads to better ovulation synchronization, such as EB, would enable us to adjust the optimal time for FTAI. Beyond that, the longer the interval between the first and last ovulation (EC treated cows) the greater will be the challenge for the semen, especially for low quality semen, to remain viable until the latter occurs.

The eCG was not able to improve DF and OF diameter until ovulation occurs and CL volume and $\mathrm{P} 4$ concentrations after ovulation in the present study as was observed in others (Tortorella et al., 2013; Núnez-Olivera et al., 2014). In cattle, eCG acts through FSH and LH receptors (Murphy and Martinuk, 1991) stimulating E2 and P4 production by DF and CL (Baruselli et al., 2004), respectively. eCG action through DF and CL is enhanced due to its long half-life (approximately 3 days), which is caused by its high sialic acid content (Murphy and Martinuk, 1991).

Cows with a satisfactory BCS and cyclic in the present study were probably the main reasons for eCG failure to improve follicular and luteal growth as expected (Barreiros et al., 2014). Other studies reported that eCG is most effective in cows with low LH pulsatility, such as in prepubertal heifers, anestrus postpartum, or cows with poor BCS (Baruselli et al., 2004;
Núnez-Olivera et al., 2014). eCG was tested during the dry season, when the decreased amount and quality of forage encourages weight loss in the animals. However, Curraleiro Pé-Duro cows did not show significant BCS reduction. Serrano et al. (2004) and Bianchini et al. (2006) reported that the small size of this breed is an adaptation to regions with food and water deficits, which confirms its hardiness, and resistance to harsh environments. In another study Teixeira et al. (2011) observed little effect caused by dry or rainy seasons on testicular biometry and fresh semen quality in Curraleiro Pé-Duro bulls, which shows their adaptability to different environmental conditions.

There was no difference in $\mathrm{P} 4$ concentration between treatment groups although eCG was able to increase the $\mathrm{P} 4$ concentration numerically in $3 \mathrm{ng} / \mathrm{ml} 10$ and 15 days after ovulation. Highest P4 concentration after conception is associated with better embryonic development (Carter et al., 2008), higher interferon- $\tau$ (IFN- $\tau$ ) production (Mann et al., 2006) and pregnancy rate (Tortorella et al., 2013).

As important as the hormonal manipulation to induce ovulation of the dominant follicle is the timing of insemination which is dependent of the timing of ovulation. The ideal time for insemination relative to ovulation depends on the lifespan of sperm which can ensure fertilization and embryo development and on the lifespan of the oocyte (Hunter, 1994). Roelofs et al. (2006) observed higher fertilization rates and embryo quality when AI was done between 24 and 12 hours before ovulation compared to AI after ovulation. No difference was found in the interval from $\mathrm{P} 4$ device removal to ovulation (IO) in Exp. 2. Thus, the optimal inseminationovulation interval in the present study is between 56 and 40 hours after device removal. Some studies in Bos taurus and Bos indicus breeds achieved satisfactory pregnancy and ovulation rates when AI was performed 48 hours after device removal regardless if EB was administered at device removal or 24 hours after device removal (Ross et al., 2004; Ayres et al., 2008; Sales et al., 2012). However, when AI was performed 54 hours after device removal, the pregnancy rate was higher in cows treated with EB 24 hours after device removal. This finding is probably due to a closer insemination-ovulation interval (less than 12 hours) because of the 
anticipated LH surge and ovulation in cows treated with $\mathrm{EB}$ at the time of device removal (Ayres et al., 2008).

\section{CONCLUSION}

Better ovulation synchronization was achieved when EB was used as an ovulatory inducer instead of CP (Exp. 1). This is important because the better the ovulation synchronization the easier it will be to choose the time for AI. However, eCG was not able to improve follicular and luteal growth (Exp. 2) probably due to the resistance of Curraleiro Pé-Duro cows that maintained a satisfactory body condition score even in a dry and hot environment. Under this circumstance, eCG does not necessarily need to be associated to a FTAI protocol in Curraleiro Pé-Duro cows, reducing costs.

\section{ACKNOWLEDGEMENTS}

The authors would like to thank CAPES for the scholarship, $\mathrm{CNPq}$ and FAP-DF for their financial support, and the Midwest Network of Postgraduate Studies, Research and Innovation. The authors state that there is no conflict of interest concerning this paper that could inappropriately influence, or be perceived to influence their work.

\section{REFERENCES}

ANUÁRIO DA PECUÁRIA BRASILEIRA. 20.ed. São Paulo: Instituto FNP, 2013. 289p.

AYRES, H.; MARTINS, C.M.; FERREIRA, R.M. et al. Effect of timing of estradiol benzoate administration upon synchronization of ovulation in suckling nelore cows (Bos indicus) treated with a progesterone-releasing intravaginal device. Anim. Reprod. Sci., v.109, p.77-87, 2008.

BARREIROS, T.R.R.; BLASCHI, W.; SANTOS, G.M.G. et al. Dynamics of follicular growth and progesterone concentrations in cyclic and anestrous suckling nelore cows (Bos indicus) treated with progesterone, equine chorionic gonadotropin, or temporary calf removal. Theriogenology, v.81, p.651-656, 2014.
BARUSELLI, P.S.; REIS, E.L.; MARQUES, M.O. et al. The use of hormonal treatments to improve reproductive performance of anestrous beef cattle in tropical climates. Anim. Reprod. Sci., v.82-83, p.479-486, 2004.

BIANCHINI, E.; CCONCEPTA, M.; LUCCI, C.M. et al. Características corporais associadas com a adaptação ao calor em bovinos naturalizados brasileiros. J. Agricult. Res., v.41, p.1443-1448, 2006.

CARTER, F.; FORDE, N.; DUFFY, P. et al. Effect of increasing progesterone concentration from day 3 of pregnancy on subsequent embryo survival and development in beef heifers. Reprod. Fertil. Develop., v.20, p.368-375, 2008.

COLAZO, M.G.; KASTELIC, J.P.; MAPLETOF, R.J. Effects of estradiol cypionate (EC) on ovarian follicular dynamics, synchrony of ovulation, and fertility in CIDR-based, fixedtime AI programs in beef heifers. Theriogenology, v.60, p.855-865, 2003.

EGITO, A.A.; MARIANTE, A.S.; ALBUQUERQUE, M.S.M. The Brazilian genetic resources conservation programm. Arch. Zootec., v.51, p.39-52, 2002.

FIORAVANTI, M.C.S.; JULIANO, R.S.; COSTA, G.L. et al. Conservación del bovino curraleiro: cuantificación del censo y caracterización de los criadores. Anim. Genet. Resour., v.48, p.109-116, 2011.

HUNTER, R.H.F. Causes for failure of fertilization in domestic species. In: ZAVY, M.T. (Ed.). Embryonic mortality in domestic species. Florida: CRC PRESS, 1994. p.1-22.

MANN, G.E.; FRAY, M.D.; LAMMING, G.E. Effects of time of progesterone supplementation on embryo development and interferon-tau production in the cow. Vet. J., v.171, p.500-503, 2006.

MARENGO, J.A. Water and climate change. Adv. Study, v.22, p.83-96, 2008.

MARIANTE A.S.; EGITO, A.A.; ALBUQUERQUE, M.S.M. et al. Managing genetic diversity and society needs. Braz. J. Anim. Sci., v.37, p.127136, 2008. 
MURPHY, B.D.; MARTINUK, S.D. Equine chorionic gonadotropin. Endocr. Rev., v.12, p.27-44, 1991.

NÚÑEZ-OLIVERA, R.; CASTRO, T.; GARCÍAPINTOS, C. et al. Ovulatory response and luteal function after eCG administration at the end of a progesterone and estradiol based treatment in postpartum anestrous beef cattle. Anim. Reprod. Sci., v.146, p.111-116, 2014.

PERRY, G.A.; SMITH, M.F.; ROBERTS, A.J. et al. Relationship between size of the ovulatory follicle and pregnancy success in beef heifers. $J$. Anim. Sci., v.85, p.684-689, 2007.

ROELOFS, J.B.; GRAAT, E.A.M.; MULLAART, E. et al. Effects of inseminationovulation interval on fertilization rates and embryo characteristics in dairy cattle. Theriogenology, v.66, p.2173-2181, 2006.

ROSS, P.J.; ALLER, J.F.; CALLEJAS, S.S. et al. Estradiol benzoate given 0 or $24 \mathrm{~h}$ after the end of a progestagen treatment in postpartum suckled beef cows. Theriogenology, v.62, p.265273, 2004.

SÁ FILHO, M.F.; PENTEADO, L.; REIS, E.L. et al. Timed artificial insemination early in the breeding season improves the reproductive performance of suckled beef cows. Theriogenology, v.79, p.625-632, 2013.

SALES, J.N.S.; CARVALHO, J.B.P.; CREPALDI, G.A. et al. Effects of two estradiol esters (benzoate and cypionate) on the induction of synchronized ovulations in Bos indicus cows submitted to a timed artificial insemination protocol. Theriogenology, v.78, p.510-516, 2012.

SARTORI, R.; FRICKE, P.M.; FERREIRA, J.C.P. et al. Follicular deviation and acquisition of ovulatory capacity in bovine follicles. Biol. Reprod., v.65, p.1403-1409, 2001.
STATISTICAL analysis system. Version 9.1. Cary: SAS Institute, 2004.

SERRANO, G.M.; EGITO, A.A.; MCMANUS, C. et al. Genetic diversity and population structure of Brazilian native bovine breeds. Braz. J. Agric. Res., v.39, p.543-549, 2004.

SOUZA, A.H.; CUNHA, A.P.; CARAVIELLO, D.Z. et al. Profiles of circulating estradiol-17 $\beta$ after different estrogen treatments in lactating dairy cows. Anim. Reprod., v.2, p.224-232, 2005.

TEIXEIRA, H.C.A.; NASCIMENTO, N.V.; MCMANUS, C. et al. Seasonal influence on semen traits and freezability from locally adapted curraleiro bulls. Anim. Reprod. Sci., v.125, p.56-61, 2011.

TORTORELLA, R.D.; FERREIRA, R.; SANTOS, J.T. et al. The effect of equine chorionic gonadotropin on follicular size, luteal volume, circulating progesterone concentrations, and pregnancy rates in anestrous beef cows treated with a novel fixed-time artificial insemination protocol. Theriogenology, v.79, p.1204-1209, 2013.

VASCONCELOS, J.L.; SARTORI, R.; OLIVEIRA, H.N. et al. Reduction in size of the ovulatory follicle reduces subsequent luteal size and pregnancy rate. Theriogenology, v.56, p.307314, 2001.

VYNCKIER, L.; DEBACKERE, M.; DEKRUIF, A. et al. Plasma estradiol-17 $\beta$ concentrations in the cow during induced estrus and after injection of estradiol- $17 \beta$ benzoate and estradiol-17 $\beta$ cypionate - a preliminary study. J. Vet. Pharmacol. Ther., v.13, p.36-42, 1990.

WILDMAN, E.E.; JONES, G.M.; WAGNER, P.E. A dairy cow body condition scoring system and its relationship to selected production characteristics. J. Dairy Sci., v.65, p.495-501, 1982. 